\title{
Water: a cause of power politics in South Asia
}

\author{
F. Naz \\ National University of Sciences and Technology (NUST), Pakistan
}

\begin{abstract}
Pakistan is naturally gifted with plentiful water resources but water is becoming a diminishing resource due to politics in the water sector both by international and domestic players. In addition, the change in climate has also threatened the world's water resources including South Asia. In South Asia, Siachin, the second longest glacier of the world has been badly affected by the presence of Indo-Pak military troops and their gun power activities.

In the early years of independence, Pakistani agriculture faced a lot of problems owing to the stoppage of water of the Indus River System by India. To overcome these problems the Indus Water Treaty between India and Pakistan was signed with the help of the World Bank in 1960 to share the water of the Indus River System. It was expected that the agreement would put an end to water issues between the two South Asia neighbours - India and Pakistan forever. However, with the passage of time there have been many constraints and violations of the treaty, causing serious water shortages for the lower riparian. Today it appears as if the wish was unsubstantiated.

The present study explores the domains and scope of hydro politics in South Asia. It gives an overview of the profile of the Indus River basin, the Indo-Pak water conflict in the wake of the Indus Water Treaty, and the technical and legal implications of the likely conflict in South Asia. The focal point of the study lies in the growth of trans-boundary environmental cooperation for sustainable hydropower development and in building up such a strategy that may surmount the internal and external security challenges to the state of Pakistan.
\end{abstract}

Keywords: trans-boundary environmental impact assessment, strategic environmental assessment, Inter-governmental Panel on Climate Change, IndoGangetic river basin, Upper Indus basin, Gilgit-Baltistan, United Nations Environment Program, International Commission on Large Dams, Permanent Indus Commission. 


\section{Introduction}

River basins in South Asia are not only the greatest sources of drinking water, irrigation and hydropower as well as being key for social, economic and environmental development. These basins pose numerous security challenges in the region. In South Asia, efficient and sustainable water resources management and yoked energy issues remain immensely valuable. The anticipated impacts of economic development, population growth and climate change on water resources, the trans-boundary cooperation becomes very crucial. In order to ward-off conflicts between riparian countries; there should be a clamour for the use of resources and sustainability.

In the early 1990s, the institutional and legal frameworks for water resources management faced difficulties in addressing the growing differences over water distribution. Climate change impacts call for improved cooperation between the riparian states. Moreover water quality aspects which have been neglected in the past are increasingly recognized as being of high relevance for regional cooperation.

The Track II dialogue between India and Pakistan discussed that "scientific studies in Pakistan and India on different crops has shown high climatic impact on agriculture. There has been $30 \%$ decrease in the yield leading to increased food insecurity. Moreover, decreasing availability of water, frequency and intensity of seasonal droughts and floods has a considerable effect on land use. The soil organic matter transformations, soil erosion, degradation of coastal agricultural lands, and low adaptive capacity to climate change also arise" [1].

Water scarcity due to climate change will impact the availability of cost efficient source of energy. Pakistan and India are already deficient in energy and import different sources of energy to fulfil their domestic demands of industry and households. Economies of both the countries are moving towards industrial development. According to estimates of the government of Pakistan, the primary commercial energy consumption growth rate is $6 \%$ per annum and is projected to raise 6.5 fold by 2030 . Natural disasters will be more prevalent, with increased frequency and intensity along with other resultant climatic extreme events. These natural disasters may cause destruction of the industry, the infrastructure, the livelihoods, and human settlement with no exemption to Pakistan and India.

The available literature indicates that in the years to come India may face water scarcity, this might be the reason behind the various hydro-power projects already constructed or in progress by the Indian government. But unfortunately this has been a cause of regional conflict among the upper and lower riparian states. It shows pursuance of Indian national interest, to store the waters for its people but in the long run it may have significant adverse implications for the whole region. For example, India is an upper riparian state to Pakistan and Bangladesh and lower riparian state to Nepal and China. In this region any inconsistent policies in the water sector may lead to water wars. 


\section{Statement of the problem}

Climate change affects the environment in a negative manner but the Himalayan glaciers of South Asia are responding differently! They are growing instead of decreasing. These glaciers are considered as the future water reservoirs for the whole region and are directly connected to the economy, agriculture, livelihoods, and food, water and energy security. However, the existing policies in the water sector may violate the right of different countries in the region to access water in an equitable way. The water sharing states neglect water as a human right they prioritise water as a national interest rather than a regional interest. It may lead towards further destabilization and water wars among the water sharing states of the region.

\section{Scope of the study}

In order to preserve the natural environment and water as a human right it is imperative to have an analysis of the existing policies in the water sector because it may open a new corridor towards robust/pro-active regional policy for adaptation and mitigation to vulnerabilities. The study will also highlight some recent controversial projects between India and Pakistan.

\section{Factors influencing conflicts, and its remedies}

\subsection{Indus river systems}

The Indus river basin system comprises of the river Indus and its five main tributaries i.e. Jhelum, Chenab, Ravi, Beas and Sutlej. It is Pakistan's lifeline and heavily reliance on its waters, makes the people across Pakistan touchy, particularly when since the last one decade waters in two main rivers Jhelum and Chenab is drastically fluctuating.

\subsection{Indus Water Treaty (IWT)}

IWT was signed in 1960 between India and Pakistan and 80\% share of water of the Indus Rivers System was allocated to Pakistan while $20 \%$ to India [2]. The Treaty gave the use of Eastern Rivers (Sutlej, Beas and Ravi) - with a mean flow of $33 \mathrm{MAF}$ - to India, while giving the use of the western rivers, Indus, Jhelum and Chenab - with a mean flow of $136 \mathrm{MAF}$ - to Pakistan.

The IWT incorporated a mechanism to exchange regularly flow-data of rivers, canals and streams and a Permanent Indus Commission (PIC) was constituted, headed by two Commissioners, one from each country. The PIC is expected to meet at least once a year alternately in India and Pakistan and submit an annual report to their respective Governments before June 30th every year [3].

However, the treaty also permitted limited use of water of Western Rivers for domestic, agriculture and for hydroelectricity generation as well. The total permissible storage of 3.6 MAF for non-consumptive use was also permitted to 
India. The conditions also stipulated in the Annexure ' $\mathrm{D}$ ' and ' $\mathrm{E}$ ' of the Treaty. The design of the hydropower plants and maximum reservoir capacity for firm power is explicitly defined in sub-clauses (a), (c), (e) and (f) of paragraph 8 of the same annexure. Annexure ' $\mathrm{C}$ ' of the treaty also allows India to irrigate a crop area of $13,43,477$ acres using the waters of the western rivers.

\subsection{Incorporation of mechanism via IWT}

The architects of the treaty offered a division of rivers and to share the waters of Indus basin for joint benefits; regretfully these provisions are the fundamental cause of friction between India and Pakistan. This is also a fact that until now India has not developed any infrastructure to stop and divert these flows on western rivers except Gyspa (Jispa) dam diversion planning project. On the other side, it is also a fact that Pakistan has never raised any objection publically on 23 different Hydroelectric Power Projects (HPP), with the cross installed capacity of 2310 Megawatt completed by India on western river and except $15 \mathrm{MW}$ Ganderbal HEP completed in 1955, all other had completed after signing of treaty in 1960 .

To date, Pakistan has only raised objections on the construction of Baglihar HPP. It is a run-of-the-river power project on the river Chenab and was conceived in 1992. After the construction began in 1999, Pakistan claimed that "some of the design parameters were too lax than needed for feasible power generation hence enabling India to accelerate, decelerate or block flow of the river" [4]. This gives India a strategic leverage in times of political tensions or war. India and Pakistan held several rounds of talks on the design of the projects during 1999-2004, but could not reach any agreement. After failure of the talks on January 18, 2005, Pakistan raised six objections to the World Bank to solve the issue. India continuously denied the objections of Pakistan and claimed that the design was in line with the provisions of the treaty.

To solve this controversy, Pakistan sent a formal request to the World Bank in April 2005 to appoint a neutral expert in order to peacefully resolve the differences arising between India and Pakistan under Article IX of the treaty, in relevance to the Baglihar Project [5]. The World Bank constituted a technical and legal team, headed by an expert, Raymond Lafitte on May 12, 2005 for adjudication. The expert delivered his final judgment on February 12, 2007, upholding India's stance regarding design of the dam, with minor modifications.

IWT clearly mention the western rivers as Pakistan's exclusive right. India can store some of its waters but being an upper riparian has to take notice of the water rights of the lower riparian. The storing should not affect the water flow and it has to be under the provisions of the IWT and ICOLD bulletins.

\subsection{Quantification of violation of the Indus Water Treaty}

Lafitte applied the Vienna Convention on the laws of treatises (1969) and referred to the latest bulletins of ICOLD rules of science and the state of the art practices. He also asserted the need to incorporate state of the art knowledge of science in the interpretation of the treaty. The verdict of the court was made 
while using emerging knowledge of hydraulic, environmental science, climate change and contemporary research on dams. The judgment of the court has become a precedence and integral part of IWT treaty. Lafitte emphasized that "the rights and obligations of both the countries should be read in the light of new technical norms and new standards as provided" [6].

During the two years of hearing, India in its counter memorial appended the verdict of International Court of Justice (ICJ) in the case of the GabcikovoNagymaros dam dispute between Slovakia and Hungary on the Danube River [7]. The ICJ declared that new norms of international environmental law are relevant for implementation of any water sharing treaty. The decision of Baglihar dam legally dictates the obligation to environmental laws and ICJ decisions. Although it is mandatory to share Environmental Impact Assessment (EIA) report of all dams in succession with ICJ decisions and ICOLD Bulletins, India has not shared EIA report of any dam with Pakistan to evaluate trans-boundary impacts.

\section{Recent controversies}

\subsection{Kishanganga Hydroelectric Project (HEP)}

It is a run-of-the-river scheme that is designed to divert water from the Kishanganga River - known as Neelum River in Pakistan to a power plant in the Jhelum River basin [8]. The construction on the project began in 2007 and is expected to be completed by 2016. The waters of the Kishanganga River are to be diverted through a 24-kilometre-long tunnel for power production. The remaining water flow will join the Wullar Lake and ultimately run through Jhelum to Muzaffarabad, evading the $213 \mathrm{KM}$ long Neelum River [9].

The Kishanganga HEP is another example of serious violation of Article - IV (3), C of the treaty and especially paragraph (5) and Article VII (b). The provision of these articles clearly restricts India to increase the catchment area of any natural or artificial drainage and drain, beyond the area on the effective date. The diversion will increase the catchment area hence resulting into violation of the IWT under the above mentioned articles.

By diverting the flow of Kishanganga River, upstream at Gurez, the catchment area of river Jhelum (tributary of main Jhelum) will be increased [10]. This may lead towards: firstly, due to adverse effects of nonavailability/reduction of water in the Neelum valley, enormous material damage may occur. Secondly, the catchment area of river Jhelum tributary will increase the flow in tributary that will cause material damage and increase likelihood of floods resulting in erosion of agriculture land along both sides of River Jhelum tributary.

If Kishanganga HEP is successfully implemented, it will result in a shortfall of almost $61 \%$ of Neelum River at Line of Control (LoC) and inflow for the NHJEP. This will reduce the project's much needed energy generation by $35 \%$ in winter season. Consequently, Pakistan will be left to suffer over 141.3 USD million dollars annually. This will also jeopardize the execution of already 
planned agricultural development activities in the area with a loss of 421 million rupees. Owing to the protest by Pakistan against the resultant multifarious effects of the construction of the dam, the construction was halted by The Hague's Permanent Court of Arbitration in October 2011.

\subsection{Cumulative impact of live storage}

Pakistan's dispute with India over the construction of an array of hydro-electric projects on the Chenab and the Jhelum rivers has turned into a source of serious tension between the two countries. Almost all Indian projects on Jhelum, Chenab and Indus are classified as run of river projects but they may entail serious consequences for downstream areas both individually and accumulatively, if IWT is not followed. when Pakistan meets the demands of water from these rivers, it may would have adverse impacts due to the accumulative live storage of these projects both in terms of causing floods and running river Chenab and Jhelum dry, in the lean period,.

\subsection{New multipurpose hydropower projects in IHK}

India has announced a hydro development plan under the 12th five year plan (2012-2017) in which 74 dams with a capacity of 15208 MW are planned. Work on some of these dams has already started [11]. India's main argument for the construction of these hydro projects is power generation. These dams have been repeatedly questioned, especially dams on the Chenab River such as:

\subsubsection{The Bursar Hydroelectric Project}

It is a storage project in which the flow of water can be regulated not only for the benefit of this project but for all downstream projects, i.e., Pakal Dul, Dul Hasti, Rattle, Baglihar, Sawalkot and Salal Hydroelectric Projects. These projects will enhance the potential of all downstream schemes. The storage provided is intended to be used for additional power generation during lean flow months and releasing regulated flow in the downstream. The storage capacity of dam will be around 2.2 MAF, while the permissible limit on Chenab River is only 1.7 MAF. The detail engineering design of all project, especially mega power project such as 1000 MW Pakaldul, 780 MW Rattle, 990 MW Kirthal and 715 MW Seli 1020 MW of Sawalkot HP have not been shared with Pakistan [12].

\subsubsection{Gyspa (Jispa) dam and river linking initiative}

Gyspa (Jispa) dam is proposed to be built at village Jispa on the Bhaga River at an altitude of 10,800 $\mathrm{ft}$ above sea level in the Lahoul-Spiti district of Himachal Pradesh, India. The proposed height of dam has capacity to store 1.2 million acre feet of water. Not only the storage of dam is in question, recently the Indian Ministry of Water Resources in the budget 2011-12 allocated funds to carry out activities related to survey, field investigation, preparation of prefeasibility/feasibility report (FRs) and details project report (DPRs) of Gyspa and Bursar Dams for inter basin transfer of water. Environmentalist and local community stared a campaign against this dam in 2006 , which ultimately drew 
the attention of the High court, which took sui-moot notice and constituted by HP High Court on hydro projects, headed by Avey Shukla, additional secretary forest HP reported on July 20, 2010 that hydro projects above $7000 \mathrm{ft}$ (above tree line) should not be built. Therefore, the Gyspa dam which is proposed to be built at an altitude of $10,800 \mathrm{ft}$ in an ecologically and geologically fragile zone goes against the committee's recommendations. The construction of Gyspa dam is completely against the ICOLD policies and the physical area itself is earthquake zone. Any natural calamity, after the construction of such a huge dam having 1.2 billion storage capacities will not only destroy Himachal Pradesh but may create serious floods in the flow of the Chenab River. This will directly affect Pakistan's agriculture, land and people.

\section{India being upper and lower riparian politics}

India being a lower riparian (in case of Brahmaputra Water conflict with China) has serious concerns over the construction of Hydro Power Project and divergence of Water towards its Yellow Sea. Indian stance is that the China's diversion of the Water of Yarlung Tsangpo river originating in Jima Yangzong glacier in south-western Tibet to its northern water-scarce areas could leave India's northeast parched. This is expected to trigger new tensions in the already difficult relations between the two Asian giants. Through the water diversion project taking off, China will acquire great power and leverage over India, worsening tensions between these two countries. On the other hand India being an upper riparian (in case of Pakistan and Bangladesh) and lower riparian (in case of Nepal) is playing power politics over water resources. The most common strategy India uses is diversion and hydro power projects on the water of the rivers that flow towards the lower riparian and being lower riparian is keeping a keen eye over the hydro power projects of the upper riparian.

\section{The impacts of India's hydro power strategy on Pakistan}

The most important water potential threats to Pakistan are identified as increased variability of monsoon and India's flood gates opening in times when the water is not required for agriculture needs in Pakistan. Under the influence of important climate change potential threats to Pakistan, the water security, food security and energy security (W.F.E.) is under serious threat; In this regard, adaptation and mitigation measures should be taken in response to vulnerabilities and resulting impacts. In order to devise a regional strategy to combat water issues, co-operation which is also mentioned in Article VII of Indus Water Treaty, that "the parties can declare their intention to co-operate by mutual agreement, to the fullest possible extent." It becomes essential between Pakistan and India on challenging long term socio-economic and environmental issues by a joint research-policy-action and sharing of technology, knowledge and experiences. The cooperation between Pakistan and India can convert the climate change challenge into an opportunity instead of playing hydro politics, for the welfare and peace of the region. Moreover, to provide comprehensive, 
participatory, policy-relevant, science-based assessment of the state and trends of the environment in South Asia to policy makers at regional level would help to resolve the existing problems.

\section{Water as a human right}

Water distribution among states has become a hot debate and emotive issue, touching people all across South Asia. In Pakistan the declining per capita water availability up to 990 cubic meters due to rising population coupled with poor water management makes situation extremely grim. The reasons behind these issues are genuine. At one side, Pakistan being primarily an agrarian country depends on the water of Indus Basin, to meet its domestic, agricultural and industrial needs. Nearly $62 \%$ of the country's population resides in rural areas, and is directly or indirectly linked with the agriculture for their livelihood. The performance of the agriculture sector of Pakistan (which accounts for about 23\% of GDP) is closely linked with the supply of water irrigation, which uses $93 \%$ of its river water. This sector remains by far the largest employee, absorbing around $45 \%$ of the country's labour force. On the other hand, the existing Indian government policies are either to stop or divert the waters not only of those rivers that flow from India to Pakistan but heavily investing in Afghanistan to affect the water flow of the river Kabul towards Pakistan. Even the Siachin glaciers are badly affected with the gun power activities between India and Pakistan. The scenario indicates that the policies are inconstant towards the environment and the unveiled strategic designs of India are highly against the human rights.

\section{Conclusions}

Firstly, water is a human right as it is essential for human, communal, national and regional sustenance. Secondly, all states are equally impacted by climate change and environment. Therefore, it is urgently required to design such policies that consider the rights, needs and vulnerabilities of all countries of the region. In this regard regional approach is required to address the existing conflicts among the water sharing states.

\section{Recommendations}

In light of these observations some recommendations are as follows;

* For Pakistan, the Indus Basin area is of great significance for the safety of its infrastructure. Therefore, to rehabilitate watershed it becomes necessary that both India and Pakistan should opt for joint watershed management.

* The Satellite based real time telemetry system needs to be installed at immediate bases as it may remove the existing mistrust on data exchange for monitoring water quality and quantity. 
* Indus Water Treaty should be followed in true spirit and all states of South Asia are obligated to design all large dams in line with ICOLD bulletins, No. 120, 121 and 123.

* An independent office of Indus Water Commission (IWC) comprising neutral experts outside of South Asian region (having unblemished record and integrity) can result in the solution of various problems.

* For sustainable flow in Indus Rivers System, it becomes mandatory that all states should share TEIA before physical execution of any project including hydropower.

* Lastly, the glaciers that are the most important and major source of Indus Rivers System needs to be preserved. In this regard there is an immediate need to declare all Himalayan Glaciers as "Protected Area" including immediate demilitarization from Siachen to preserve this second longest glacier of planet to fall in the watershed of the Indus River.

\section{References}

[1] Pakistan-India Track II Dialogue on Climate Change, Islamabad, Pakistan, 11 to 18 February 2012

[2] Indus Water Treaty: the Negotiating Process, Water International, Volume 17, Issue 4, 1992

[3] The India-Pakistan Peace Process: IRS Regional Brief, July-August 2012 No. 31

[4] Zentner, M.: Design and Impact of Water Treaties: Managing Climate Change, New York: NY Springer, 2012

[5] Khataq Amer. Rizwan: World Bank Neutral Experts Determination on Baglihar Dam: Implications for India-Pakistan relations, Pakistan Horizon, 2008

[6] Mathew Zenthner: Design and Impact of Water Treaties: Managing Climate Change, Springer, 2012

[7] Water Politics: The Parched Tiger: India's Dam Industrialization Program January 16th, 2012

[8] Dhirendra Vajpai: Water Resource Conflicts and International Security: A Global Perspective, Lexington Books, 2012

[9] Laurence Boisson De Chazournes, C. Leb, Mara Tignino: International Law and Freshwater: The Multiple Challenges, Edward Elgar, 2013

[10] Mushtaq Ghumman: Neelum-Jhelum project contract awarding: delay led India to begin Kishanganga hydel works, Emmayzed Publications (PIT) Ltd, 2011

[11] Sustainable Development and Planning Institution Pakistan Report

[12] Abdul Rauf Iqbal: Water wars and Navigating Peace over Indus River Basin, Islamabad, National Defence University, 2010 